\title{
MODIFIKASI PEKERJAAN RUMAH (PR) SEBAGAI WAHANA PENGUATAN PENDIDIKAN KARAKTER
}

\author{
Umi Latun \\ SDN Rejowinangun Utara 3 \\ Email: umiastimi@gmail.com
}

\begin{abstract}
ABSTRAK
Sumber daya yang bermutu dan berkarakter menjadi modal utama pembangunan Indonesia seutuhnya. Pemerintah telah menargetkan adanya revolusi karakter bangsa melalui gerakan Penguatan Pendidikan Karakter. Dalam implementasinya di sekolah, ada beberapa cara untuk membangun karakter siswa. Salah satunya adalah melalui modifikasi pekerjaan rumah (PR), yaitu dengan memberikan tugas rumah kepada siswa dengan pelibatan keluarga agar memiliki karakter yang baik atau bahkan lebih baik dan prestasi belajar meningkat. Kegiatan semacam ini sesuai dengan harapan pemerintah dalam pembangunan karakter bangsa melalui program penguatan pendidikan karakter (PPK) yang lebih ditekankan lagi dalam kurikulum 2013 dimana setiap mata pelajaran harus berkontribusi dalam pendidikan karakter yang mencakup aspek relegius/spiritual dan aspek sosial yang dalam pelaksanaannya dapat dilakukan melalui berbagai media, dengan tempat di mana saja dan dengan siapa saja, dalam arti dapat dilaksanakan dengan selain guru. Modifikasi pekerjaan rumah (PR) memenuhi harapan tersebut. Hasilnya terbukti signifikan serta efisien, efektif, ekonomis, hasilnya lestari dan merupakan langkah inovatif. Dalam hal ini siswa meningkat karakter dan prestasinya ke arah yang lebih baik.
\end{abstract}

Kata kunci:

Penguatan pendidikan karakter (PPK), modifikasi pekerjaan rumah (PR).

\section{PENDAHULUAN}

Bangsa Indonesia memerlukan sumber daya manusia dalam jumlah dan mutu yang memadai sebagai penggerak pembangunan. Dari sisi jumlah, penduduk Indonesia usia produktif telah mencukupi, namun dari mutu perlu ditingkatkan lagi. Sumber daya yang mutu mengacu pada dua hal. Pertama, memiliki kapabilitas yang mencakup pengetahuan dan keterampilan. Kedua, memiliki karakter keindonesiaan yang kuat agar ilmu dan keterampilan yang dimiliki bermakna bagi dirinya, masyarakat, bangsa, dan agama.

Di era global seperti sekarang ini, ancaman hilangnya karakter semakin nyata. Nilai-nilai karakter yang luhur tergerus oleh arus globalisasi, utamanya kesalahan dalam memahami makna kebebasan sebagai sebuah demokrasi dan 
rendahnya filosofi teknologi. Kemajuan teknologi adalah pisau bermata dua, di satu sisi memberi kemudahan bagi umat manusia, di sisi lain memberi dampak negatif jika disalahgunakan.

Pendidikan karakter mendesak untuk dilaksanakan. Ada gejala-gejala yang menandakan tergerusnya karakter bangsa ini. Tanda-tanda merosotnya karakter bangsa ini, senyampang apa yang dinyatakan Thomas Lickona, diantaranya meningkatnya kekerasan di masyarakat, penggunaan bahasa dan kata-kata yang memburuk/ tidak baku, meningkatnya perilaku merusak diri, seperti penggunaan narkoba, semakin rendahnya rasa hormat kepada orang tua dan guru, serta perilaku tidak bertanggung jawab di mana-mana.

Dampak dari merosotnya karakter secara individu, terlihat jika seseorang melakukan salah satu tindakan ( tanda-tanda merosotnya karakter bangsa di atas), berpotensi bermasalah dengan hukum, terlibat dalam kekerasan, hilangnya percaya diri, dan menjadi individu yang tidak memiliki karakter.

Berdasarkan fenomena di atas diperlukan upaya penanaman karakter sejak dini. Salah satu upaya tersebut adalah melalui modifikasi PR (pekerjaan rumah). Penanaman pendidikan karakter melalui modifikasi PR ini diterapkan pada siswa kelas 1 SDN Rejowinangun Utara 3 Kota Magelang. Kegiatan ini sebagai langkah kecil bentuk dari merdeka belajar dalam rangka menyiapkan generasi emas Indonesia 2045.

Guru sebagai pendidik yang berinteraksi langsung dengan siswa memiliki tugas dan peranan yang sangat penting. Tugas guru tidak hanya sekedar menyampaikan materi pembelajaran saja, tetapi guru harus bisa mendidik siswa menjadi generasi yang unggul dan berkarakter. Kurikulum 2013 telah menjawab berbagai permasalahan pengembangan karakter dengan menempatkan karakter sebagai salah satu tujuan utama pendidikan. Pengembangan sikap spiritual dan sikap sosial yang menjadi kompetensi inti pada kurikulum 2013 diharapkan akan menjadi pilar untuk mengembangkan karakter anak di satuan pendidikan.

Namun, pendidikan karakter tidak dapat ditanamkan dan dibentuk hanya oleh guru di sekolah. Karakter tidak bisa terbentuk hanya melalui 4-6 jam pertemuan setiap hari. Kunci pendidikan karakter ada dalam keluarga. Orangtua 
sebagai pendidik pertama dan utama memegang peranan penting dalam pengembangan karakter anak. Sebagaimana contoh penanaman karakter kejujuran. Guru bisa menanamkan kejujuran melalui setiap pembelajarannya, misalnya dalam penugasan atau ulangan. Di rumah pun orang tua harus mendukung misalnya dalam mengerjakan pekerjaan rumah (PR). Orang tua bisa membimbing dan mengarahkan agar anak jujur mengerjakan. Selain kejujuran, dalam mengerjakan PR bisa melatih kemandirian dan tanggung jawab anak.

Berdasarkan observasi awal yang dilakukan peneliti pada Agustus 2018 menunjukkan bahwa siswa kelas 1 ketika mendapat pekerjaan rumah dari guru, hari berikutnya ada saja yang tidak masuk sekolah. Jika hari berikutnya masuk kembali, ketika ditanya alasan mengapa tidak masuk sekolah, rata-rata menjawab karena belum mengerjakan PR. Ditemukan juga ketika mengoreksi PR siswa, hasil pekerjaan mereka bukan hasil tulisan sendiri. Ketika ditanya siswa menjawab dituliskan ibu atau kakak mereka. PR menjadikan mereka sering tidak masuk sekolah dan nilai kejujuran menurun.

Berdasarkan latar belakang masalah di atas maka peneliti tertarik untuk mengadakan penelitian lebih lanjut tentang "Modifikasi Pekerjaan Rumah (PR) sebagai Wahana Penguatan Pendidikan Karakter Siswa Kelas 1 SDN Rejowinangun Utara 3 Kota Magelang”.

Dari latar belakang masalah yang telah dikemukakan sebelumya, maka berbagai permasalahan yang dapat teridentifikasi adalah sebagai berikut: 1) Sikap siswa belum dapat menanggapi secara positif pemberian pekerjaan rumah dari guru. 2) Peran guru dalam pemberian pekerjaan rumah masih kurang dapat meningkatkan karakter siswa .

\section{Kajian Pustaka}

\section{Pekerjaan Rumah (PR)}

Pekerjaan Rumah (PR) atau dalam bahasa Inggris "homework" yang artinya mengerjakan pekerjaan rumah. Pekerjaan rumah adalah sebuah tugas atau pekerjaan tertentu yang harus dikerjakan di luar jam sekolah (terutama di rumah) berkaitan dengan pelajaran yang telah disampaikan guru untuk meningkatkan penguasaan konsep atau 
keterampilan dan memberikan pengembangan. Pemberian tugas yang diberikan guru terhadap siswa secara teratur dan berkala dapat menanamkan sikap dan kebiasaan belajar yang positif yang pada gilirannya dapat mendorong siswa untuk belajar sendiri. PR disebut juga sebagai alat komunikasi antara guru, orang tua dan siswa. Pekerjaan rumah diberikan dengan harapan agar orang tua dapat berperan aktif dalam pengerjaannya.

Menurut Partin (2009: 101) Pemberian PR dapat diberikan guna melengkapi pilihan pengerjaan bagi siswa yang tertinggal dalam pengembangan keterampilan.

Paparan di atas dapat diambil kesimpulan bahwa pekerjaan rumah adalah tugas yang diberikan guru kepada siswa, yang wajib dikerjakan oleh siswa dirumah atau diluar jam sekolah, serta orang tua berperan penting untuk membimbing dan memperhatikan anak dalam mengerjakan PR. Dengan demikian anak akan merasa senang untuk mengerjakan PR.

PR adalah tanggung jawab anak. Jangan pernah mengambil alih tanggung jawab itu. Biarkan ia belajar mengambil keputusan untuk mengerjakan atau tidak mengerjakannya. Dengan tanggung jawabnya dan tugas yang dihadapinya anak akan terbantu untuk kemampuan memecahkan masalah. Anak-anak dengan kebiasaan-kebiasaan yang baik secara otomatis cenderung berprestasi lebih baik di sekolah dan dalam hidup mereka selanjutnya.

\section{Modifikasi Pekerjaan Rumah (PR)}

Modifikasi pekerjaan rumah (PR) merupakan salah satu strategi untuk memberikan pengalaman belajar yang dapat meningkatkan cara belajar yang lebih baik. Sebenarnya, pemberian PR memiliki tujuan baik. Sayangnya, kadang pemberian PR yang bertujuan sebagai pelajaran tambahan di rumah ini terlalu banyak porsinya. Pekerjaan rumah yang terlalu banyak akan menyita waktu anak bercengkerama dengan keluarga dan bermain dengan teman sebaya di lingkungan rumahnya. 
Jika PR lebih bertujuan agar siswa melatih materi yang telah diajarkan di sekolah, maka modifikasi PR memiliki tujuan lain. Modifikasi PR bertujuan untuk mengembangkan kreativitas, kemampuan komunikasi, manajemen diri, dan manajemen waktu. Jika PR cenderung menjadi proyek individu siswa, maka modifikasi PR lebih bercita rasa keluarga. Modifikasi PR dirancang untuk melibatkan orang-orang di sekitar siswa. Keteladanan dari orangtua dan orang-orang di lingkungan sekitar anak akan menjadi modal anak dalam berperilaku. Anak adalah peniru ulung. Apa yang dilihat oleh anak, didengar oleh anak, orang-orang yang berada di sekitar anak akan menjadi panutan anak dalam berperilaku. Perilaku anak adalah cerminan dari perilaku orang-orang yang berada di sekitar anak. Interaksi yang terjadi dalam keluarga akan menjadi model perilaku yang ditiru oleh anak. Ketika setiap hari anak melihat ayah ibunya selalu bangun pagi setiap hari dan mengawali dengan kegiatan ibadah, dan membiasakan anak-anaknya melakukan hal yang sama, maka karakter disiplin dan religius juga akan tertanam dalam diri anak.

Karakter tidak akan terbentuk dalam waktu singkat. Tidak cukup satu dua hari, satu dua minggu atau satu dua bulan dalam membentuk karakter anak. Dalam hal ini orangtua harus sabar, konsisten, dan selalu mendampingi anak dengan kasih sayang.

Diperlukan satu bahasa dalam mengembangkan karakter anak sejak dini. Kesamaan nilai-nilai dalam keluarga, antara ibu dan ayah akan memudahkan dalam mengembangkan karakter anak sejak dini. Konsistensi dalam mengajarkan mana yang boleh dan mana yang tidak boleh dilakukan menjadi dasar bagi terbentuknya kebiasaan sebagai awal pengembangan karakter anak.

Anak akan dengan mudah mengadopsi nilai-nilai karakter dalam keluarga ketika anak melihat bahwa seluruh anggota keluarga melakukannya setiap hari. Untuk itu, diperlukan konsistensi dan kesamaan pandang dalam mengimplementasikan karakter di keluarga setiap harinya. 
Teori manajemen mengajarkan bahwa setiap kegiatan apabila direncanakan dengan baik akan membawa hasil yang baik pula. Demikian pula modifikasi pekerjaan rumah (PR) yang bermuatan karakter. Perancangan modifikasi pekerjaan rumah (PR) menggunakan tabel Substansi Nilai/Karakter pada stándar kompetensi lulusan (SKL) untuk menentukan nilai/karakter yang akan dikembangkan.

Modifikasi pekerjaan rumah (PR) dirancang sekreatif mungkin dengan tidak meninggalkan kompetensi dasar pengetahuan yang harus dicapai oleh siswa. Tampilan PR didesain unik. Ada foto siswa, keterangan tema dan identitas kompetensi dasar. Terdapat sudut orang tua, untuk memberi petunjuk, bantuan apa yang bisa diberikan kepada anak. Dilengkapi juga dengan kolom komentar guru dan orang tua. Kolom komentar orangtua sebagai ruang refleksi dari apa yang telah diberikan guru kepada anak-anak, sedangkan kolom komentar guru sebagai umpan balik tertulis, berupa pujian, pemberian motivasi, maupun arahan untuk perbaikan selanjutnya. Materi modifikasi PR juga menantang, berisi aktivitas yang menggali pengetahuan dan keterampilan anak. Bahasa dan tulisan berbeda dengan biasanya. Tujuannya paling tidak, siswa senang membacanya.

- Modifikasi PR adalah media bagi siswa untuk mencurahkan kreativitas dan dalam penyelesaian masalah. Sifatnya aplikatif, dan bisa menuntun siswa menemukan manfaat dari pelajaran.

- Modifikasi PR itu menyenangkan; bukan hanya tugas yang harus dikerjakan, tapi juga sarana bersenang-senang.

- Modifikasi PR melatih anak untuk menjalani proses penyelesaian masalah, melatih motorik, berpikir, sosial, dan emosi.

- Modifikasi PR mengajak anak peka terhadap lingkungan. Tugastugasnya didesain agar siswa belajar untuk kemampuan bersosialisasi dengan masyarakat dan lingkungan, komunikasi, dan kepemimpinan. 


\section{Penguatan Pendidikan Karakter}

Dalam Peraturan Menteri Pendidikan dan Kebudayaan Nomor 20 Tahun 2018 tentang Penguatan Pendidikan Karakter (PPK), pada pasal 1 dinyatakan PPK adalah gerakan pendidikan di bawah tanggung jawab satuan pendidikan untuk memperkuat karakter peserta didik melalui harmonisasi olah hati, olah ras, olah pikir, dan olah raga dengan pelibatan dan kerja sama antara satuan pendidikan, keluarga, dan masyarakat sebagai bagian dari Gerakan Nasional Revolusi Mental (GNRM). Lebih lanjut pada pasal 2 dinyatakan bahwa (1) PPK dilaksanakan dengan menerapkan nilai-nilai Pancasila dalam pendidikan karakter terutama meliputi nilai-nilai religius, jujur, toleran, disiplin, bekerja keras, kreatif, mandiri, demokratis, rasa ingin tahu, semangat kebangsaan, cinta tanah air, menghargai prestasi, komunikatif, cinta damai, gemar membaca, peduli lingkungan, peduli sosial, dan tanggung jawab. Nilai-nilai tersebut merupakan perwujudan dari 5 (lima) nilai utama yang saling berkaitan, yaitu religiusitas, nasionalisme, gotong royong, dan integritas yang terintegrasi dalam kurikulum.

\section{METODE}

Penelitian dilaksanakan pada semester gasal tahun pelajaran 2018/2019, dengan lama penelitian 5 bulan terhitung sejak Agustus sampai dengan Desember 2018. Penelitian dilaksanakan di kelas 1 SD Negeri Rejowinangun Utara 3 Kota Magelang. Sesuai dengan tujuan penelitian, maka penulis melakukan penelitian ini secara tindakan. Penelitian tindakan dapat dilukiskan sebagai sebuah siklus yang melibatkan langkah-langkah perencanaan, pelaksanaan, observasi, dan refleksi. Populasi dalam penelitian ini adalah siswa kelas 1 SDN Rejowinangun Utara Kota Magelang tahun pelajaran 2018/2019 dengan jumlah 13 orang yang terdiri dari 11 siswa laki-laki dan 2 siswa perempuan. Dalam penelitian ini teknik pengambilan sampel yang digunakan adalah sampling jenuh yaitu semua populasi diteliti. 
Variabel bebas dalam pengembangan sekolah ini adalah modifikasi Pekerjaan Rumah (PR), sedangkan variabel terikat adalah penguatan pendidikan karakter siswa yang dilaksanakan oleh guru kelas 1 SDN Rejowinangun Utara 3 Kota Magelang. Data penelitian bersumber dari buku catatan pemberian PR, daftar hadir siswa, catatan kejadian dan daftar nilai siswa kelas 1 SDN Rejowinangun Utara 3 Kota Magelang. Instrumen yang digunakan dalam penelitian ini antara lain: 1) Catatan pemberian Pekerjaan Rumah (PR); 2) Catatan kejadian; 3) Daftar nilai siswa; dan 4) Jurnal penilaian sikap spiritual dan sikap sosial siswa.

Data yang diperoleh dalam penelitian ini dianalisis dengan terlebih dahulu menyeleksi data untuk disederhanakan guna lebih memfokuskan penelitian. Data kemudian diorganisasikan secara sistematis dan rasional untuk mengkaji bahan penelitian demi merasionalkan tampilan bahan. Instrumen yang digunakan dalam penelitian adalah: 1) Daftar kehadiran siswa; 2) Catatan pemberian PR; 3) Catatan kejadian; dan 4) Lembar observasi sikap spiritual dan sikap sosial siswa. Proses pengolahan data yang diperoleh dalam kegiatan observasi awal selanjutnya dianalisis dengan menggunakan teknik diskriptif komparatif yakni membandingkan data kehadiran siswa di sekolah dengan data nilai siswa.

\section{HASIL DAN PEMBAHASAN}

Dari daftar hadir siswa sebelum dilakukan tindakan adalah sebagai berikut:

\begin{tabular}{lll}
\hline No & Bulan & Kehadiran Siswa (\%) \\
\hline 1 & Juli & 94 \\
2 & Agustus & 80 \\
\hline
\end{tabular}

Dari catatan perhitungan kehadiran siswa setelah dilakukan tindakan adalah sebagai berikut: 


\begin{tabular}{lll}
\hline No & Bulan & Kehadiran Siswa (\%) \\
\hline 1 & September & 85 \\
2 & Oktober & 90 \\
3 & November & 98 \\
4 & Desember & 100 \\
\hline
\end{tabular}

Dari jurnal penilaian sikap spiritual dan sikap sosial siswa sebelum dilakukan tindakan adalah sebagai berikut:

\begin{tabular}{|c|c|c|}
\hline No & Bulan & Sikap Siswa \\
\hline 1 & Juli & - Sebagian besar siswa masih menunjukkan \\
\hline \multirow[t]{6}{*}{2} & Agustus & sikap kurang kyusuk dalam berdoa, kurang \\
\hline & & percaya diri, kurang berani, egois, terlambat \\
\hline & & masuk kelas, dan tidak masuk sekolah \\
\hline & & dengan berbagai dalih. \\
\hline & & - Dinamika hubungan sosial anak, diantaranya \\
\hline & & : pertengkaran, salah paham, saling ejek. \\
\hline
\end{tabular}

Dari jurnal penilaian sikap spiritual dan sikap sosial siswa setelah dilakukan tindakan adalah sebagai berikut:

\begin{tabular}{|c|c|c|}
\hline No & Bulan & Sikap Siswa \\
\hline 1 & September & - $\quad$ Siswa lebih khusyuk dalam berdoa sebelum \\
\hline 2 & Oktober & dan sesudah kegiatan, lebih percaya diri \\
\hline 3 & November & tampil di kegiatan kelas, mandiri dalam \\
\hline 4 & Desember & $\begin{array}{l}\text { kegiatan mengurus kepentingan pribadi, lebih } \\
\text { tertib dalam mengikuti upacara bendera } \\
\text { (dalam sikap maupun kelengkapan seragam). }\end{array}$ \\
\hline & & $\begin{array}{l}\text { - Peningkatan prosentase kejadian positif } \\
\text { dinamika hubungan sosial anak }\end{array}$ \\
\hline
\end{tabular}


Prosentase kehadiran siswa pada tiap bulan selalu ada peningkatan. Pemberian pekerjaan rumah (PR) menggunakan modifikasi PR dapat meningkatkan semangat belajar siswa ke sekolah. Hasil belajar dapat meningkat bila kehadiran siswa juga meningkat. Pemberian pekerjaan rumah (PR) melalui modifikasi PR adalah salah satu alternatif untuk meningkatkan aktivitas belajar siswa di rumah. Agar PR itu menjadi aktivitas yang menyenangkan, pendidik harus merancang PR semaksimal mungkin, sehingga siswa senang dan tidak merasa terbebani.

Melalui pemberian tugas rumah dengan menggunakan modifikasi $P R$ ini diharapkan semua siswa aktif dengan melibatkan orang-orang di sekitarnya. Modifikasi PR yang sarat bermuatan karakter akan membentuk kepribadian siswa.

Untuk melihat perbandingan peningkatan karakter siswa sebelum dan sesudah diterapkan penggunaan modifikasi PR dapat dilihat pada tabel sebagai berikut:

\section{Tabel 8. Perbandingan Antara Sebelum dan Sesudah Diterapkan Modifikasi PR}

\begin{tabular}{|c|c|c|c|}
\hline \multirow{2}{*}{$\begin{array}{l}\text { Penilaian } \\
\text { Prosentase } \\
\text { Pada }\end{array}$} & \multirow{2}{*}{$\begin{array}{l}\text { Rata-rata } \\
\text { Kehadiran } \\
\text { Siswa } \\
\text { (bulan) }\end{array}$} & \multicolumn{2}{|c|}{ Kejadian } \\
\hline & & Negatif & Positif \\
\hline Sebelum & $87 \%$ & $60 \%$ & $40 \%$ \\
\hline Sesudah & $93 \%$ & $15 \%$ & $85 \%$ \\
\hline
\end{tabular}

Dengan strategi modifikasi PR dalam pemberian pekerjaan rumah, kehadiran siswa di sekolah mengalami peningkatan. Prosentase rata-rata kehadiran siswa tiap bulan sebelum diterapkannya modifikasi PR sebesar 87\%, sedangkan rata-rata prosentase kehadiran siswa setelah diterapkannya modifikasi PR sebesar 93\%, terjadi peningkatan sebesar 6\%. Pada prosentase kejadian sebelum adanya modifikasi PR, kejadian negatif lebih banyak terjadi yaitu sebesar $60 \%$ dan kejadian positifnya sebesar $40 \%$. Setelah diterapkannya modifikasi PR, 
prosentase kejadian positif menjadi $85 \%$, terjadi peningkatan sebesar $35 \%$. Sedangkan kejadian negatif menjadi $15 \%$, terjadi penurunan sebesar $45 \%$.

Melalui modifikasi PR siswa menemukan pembelajaran yang menarik, sehingga lebih bersemangat ke sekolah serta berperilaku positif. Dari uraian di atas dapat disimpulkan bahwa melalui modifikasi PR memberikan pengaruh positif dan efektif terhadap aktivitas serta karakter siswa di kelas 1 SDN Rejowinangun Utara 3. Sehingga tujuan akhir dari pembelajaran terwujudnya insan berilmu dan berkarakter dapat dtercapai.

\section{SIMPULAN}

Modifikasi Pekerjaan Rumah (PR) berpengaruh terhadap pembentukan karakter siswa. Prosentase ketidakhadiran siswa di kelas menurun, sehingga siswa dapat mengikuti materi pelajaran secara maksimal. Kejadian positif semakin meningkat berdampak pada kondusifnya kegiatan pembelajaran.

Pemberian tugas rumah berupa modifikasi pekerjaan rumah (PR), merupakan salah satu strategi pembelajaran dengan pelibatan orang tua. Melalui modifikasi pekerjaan rumah (PR) yang disajikan dengan menarik, didesain agar siswa belajar untuk kemampuan bersosialisasi, memberi alternatif kegiatan yang melatih kepekaan, baik kepekaan sosial maupun kepekaan alam sebagai upaya penguatan pendidikan karakter, baik nilai religiusitas, nasionalisme, kemandirian, gotong royong dan integritas.

\section{DAFTAR PUSTAKA}

Arifin, M. 2015. Strategi dan Kebijakan Pembelajaran Pendidikan Karakter. Yogyakarta: Ar-Ruzz Media

Farida, Anna. 2019. Sekolah yang Menyenangkan. Bandung: Nuansa Cendekia Majid, Abdul Aziz. 2013. Mendidik dengan Cerita. Bandung: Rosdakarya Sayid, Abdulbasith Muhammad. 2008. Nabi sebagai Guru. Sukoharjo: Al-Qowam Suryanto, Cucu. 2014. Guru Berkarakter Guru Profesional Masa Depan. Sukoharjo: Farishma Indonesia

Zulfanah, Amir Faisal. 2014. Pendidikan Karakter. Sukoharjo: Farishma Indonesia 